\title{
Resignification as Fourth Narrative: Power and the Colonial Religious Experience in Tula, Hidalgo
}

\author{
Shannon Dugan Iverson
}

Scholars have typically described colonial religious change in Mesoamerica in one of three major narrative frames:

(1) the "spiritual warfare narrative": a top-down imposition of Christianity;

(2) the "core-veneer narrative": a largely failed colonial project in which indigenous subjects retained many of their essential religious traits; or

(3) the syncretism narrative: a passive, relatively equal blending of two originally coherent belief systems.

These debates are, at their core, ideas about the way that power operates in early colonial situations, and each constitutes a narrative of power that is enabled, strengthened, challenged, and refined by empirical data.

However, as I worked through the data I collected from two early Franciscan sites in Tula, Hidalgo in central Mexico (Figure 12.1), I found that existing narratives of religious change were inadequate to interpret the full extent of the transformations and continuities that I was observing. These data pointed toward a complex but unequal exchange: indigenous subjects clearly did not have full autonomy in early colonial Christian contexts, yet their diverse preexisting religious ontologies shaped the New World Church to a remarkable degree. This finding, though shared with many other researchers with similar topics (Graham 2011; Tavárez 2011; Wernke 2007), did not fit well with established narratives of colonial religious power. This was not an "ideal-type" problem: that is, the inherent mismatch between real-world data and inherently inadequate "ideal-type" models. Rather, there seemed to be a gap where a fourth narrative should be. Even so, the old "commonsense" narratives of religious change seemed to stubbornly persist despite ample data and careful refutations of existing models. Finding an interpretation of colonial power that articulated honestly with my data became my most challenging task.

To contextualize the Tula case, I explain existing narratives of religious change in the region. I then contrast two forms of material culture from Tula - buildings and ceramics - that, at least superficially, appear to tell opposite 


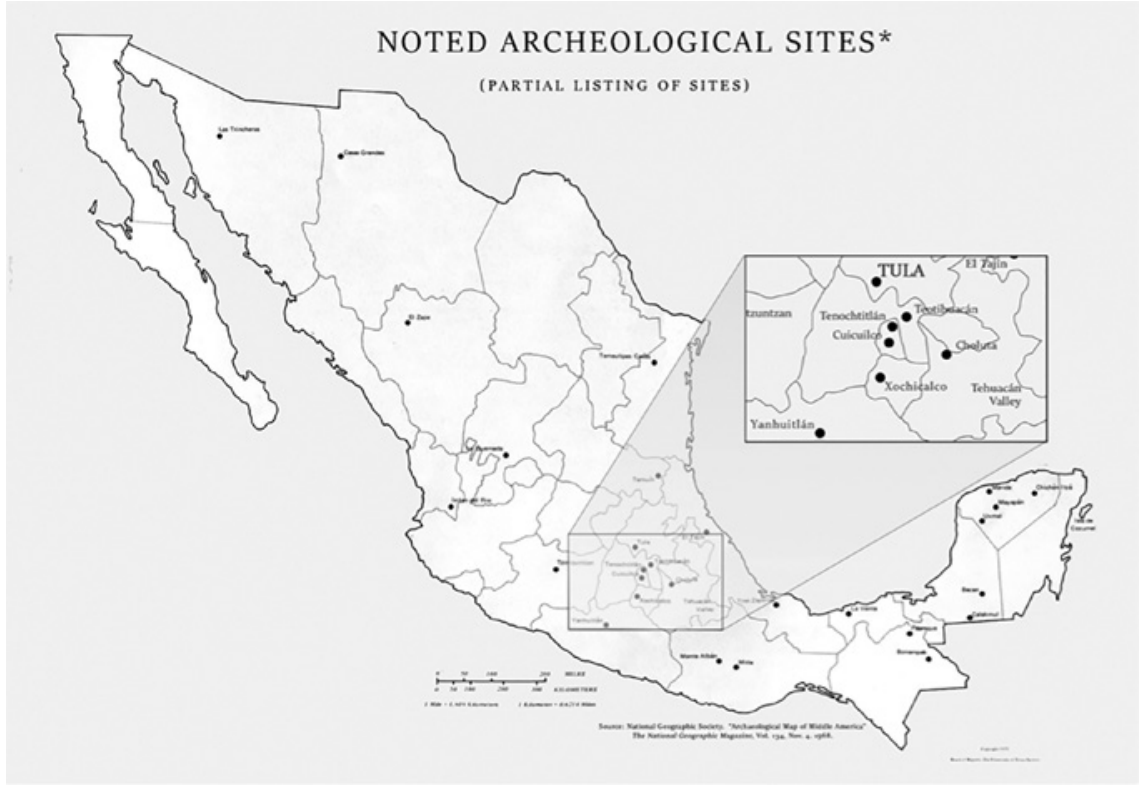

FIGURE 12.1 The location of Tula, Hidalgo in central Mexico. Adapted from "Noted Archaeological Sites," Board of Regents, University of Texas 1975 IMAGE COURTESY OF UNIVERSITY OF TEXAS LIBRARIES, UNIVERSITY OF TEXAS AT AUSTIN

stories about the evangelization program in that city. Closer analysis revealed that indigenous preferences played a significant role in shaping each material category. Nonetheless, that influence took place within the context of "social and cultural conversion of entire ethnic groups as a part of colonial domination" (Hansk 2010, 5): indigenous contributions to Christianity were not necessarily intentional, peacefully negotiated, or the product of overt or covert resistance. In the concluding section, I propose a "fourth narrative" based on Judith Butler's (1990) concept of resignification that provides a balanced account of these two known phenomena (indigenous contributions to Catholicism and the domination of the Church), and in so doing offers a more powerful explanation of the material patterns at Tula.

\section{$2 \quad$ Religion in Early Colonial Mexico}

For over 1500 years, Mesoamerican and Spanish religious traditions developed independently of one another. The former's roots developed out of their Teotihuacano and Toltec heritage, pan-regional interactions, and tensions between 
the rural and state-oriented aspects of Aztec religious systems (Berdan 2014, 33-36; Brumfiel 2001; López Austin and López Luján 2000). The Spanish traditions were the product of tensions and interactions between idiosyncratic rural paganism, Moorish influences, Sephartic Jewish traditions, the Crusades, and the evolving relationship between the Church and the Spanish Empire (Christian 1989). These two complex, heterogeneous traditions did not come into regular contact until the Spanish conqueror Hernán Cortés arrived on the shores of Veracruz and began his campaign to overthrow the Aztec Empire.

The Spanish Empire used Christianity to justify its own expansion, and Cortés' campaign traveled with a Franciscan mendicant who haphazardly fulfilled the Crown's religious obligations to convert the indigenous subjects of the New World to the "true faith" (Díaz 1963). In 1521, once the military conquest was complete, Cortés requested that the Crown send a group of mendicants to begin the "spiritual conquest" of the new territory. The band of Franciscans, known as "The Twelve" after the apostles of Christ, arrived in 1524 and quickly set about demolishing the outward remnants of the Aztec state religion: the temples, priesthood, sacred books, and monthly public ceremonies (Ricard 1966). In their place, they established new Christian places of worship, performed mass baptisms, and changed the focus of worship to the Christian God and saints (Ricard 1966; Schwaller 2011).

But friars' Utopian ambitions (Gómez-Herrero 2001) to remold the very foundations of indigenous worship met many challenges. Friars faced outright resistance. They also faced the "resistance of culture", that is, the resistance asserted by the force of preexisting social and geographical structures (see Wernke 2007 for an analogous case in Peru). Epidemic disease decimated the indigenous population, which resulted in major population shifts (Hanks 2010, $3^{2}$ ), just as the plagues had in the Old World (Christian 1989). The two societies faced one another with fundamental misunderstandings: concepts such as sin were alien to the indigenous peoples, while the Spanish could not understand practices such as sacrifice (Cervantes 1997; Gibson 1964). Linguistic translation was a theological minefield (Hanks 2010; Ricard 1966). The friars also faced very low ratios of monastics to indigenous populations (Hanks 2010, 41) which made friars' individual ideas and preferences more salient and bred variation (Graham 2011, 286). Then, too, there were philosophical differences between the orders themselves, between the orders and the secular priests, and squabbles between the Crown and the orders (Ricard 1966).

Most importantly, the friars faced the proactive engagement of indigenous subjects in Christianity, which fundamentally changed the nature of ritual and the nature of Christianity itself (Burkhart 1989, 1998; Cervantes 1997; Gibson 1964; Graham 2011; Lockhart 1992; Pardo 2006). As scholars have learned more about pre-Columbian religions, languages, and lifeways it has become 
increasingly clear that indigenous ways of being informed the foundations of colonial Mexican societies (Burkhart 1989, 1998; Gibson 1964; Lockhart 1992).

The violence and domination of the Church, the active contributions of indigenous subjects to Christianity, the reinterpretations and innovations within novel religious contexts: these were all realities of the early colonial evangelization program that existed simultaneously. We need a way out of established narratives that overstate the monolithic power of the Church (Schwaller 2011), as well as narratives that set up a false dominance/resistance binary. And we need new narratives that can honestly account for the complexities of the material record, which point to indigenous influence that was not the result of intentional resistance, peaceful cultural exchange, or an accident of circumstance. Rather, heterogeneous indigenous religious traditions informed and transformed Catholicism. I argue that this transformation was the direct resultintentional or not, coerced or not - of active indigenous participation in the early Church.

\section{3}

\section{Narratives of Colonial Religious Change}

Narrative, Frederic Jameson (2013, xiii) tells us, is "the central function or instance of the human mind"; stories are what our brains are built to do (Bruner 2004). Narrative allows us to make sense of mundane and extraordinary events, and through repetition, allows societies to collectively make sense of the past (Connerton 1989). This process takes place at levels ranging from the individual - the autobiographical story (Bruner 2004) - to the structural: the "national narrative," for example.

Studies from multiple disciplines reveal that our narrative repertoires are limited. Hayden White (2009) has argued that traditional historical narratives are constructed according to a limited set of archetypes that structure historical events into recognizable storylines ("progress," for example, or "the hero's journey"). Naming these limited narratives and providing empirical evidence that counteracts them has been a productive strategy for scholarly and popular texts. For example, Restall's (2004) "Seven Myths of the Spanish Conquest" identified and dismantled narratives of the early colonial past that continue to persist in the popular imagination. Similarly, Enrique Rodríguez-Alegría identified a problematic notion within recent popular media, "the narrative of quick replacement," that wrongly assumed that "superior" European tools and technologies quickly replaced indigenous technologies. In fact, evidence shows that the production of indigenous obsidian tools increased in the colonial era (Rodríguez-Alegría 2008). Material culture is an effective tool for challenging 
inaccurate, "commonsensical," and partial narratives about the past. However, if narrative's efficacy is constructed through repetition and by building order, it is not enough to test old narratives and reveal their gaps and inaccuracies. Ultimately, we have to construct new narratives.

Existing narratives of colonial religious conversion practices are based primarily on documents compiled by sixteenth- and seventeenth-century mendicants (e.g., de Alarcón 1987; de Mendieta 1870; Durán 1971; Sahagún 1950) as well as men who had participated in the conquest (Díaz 1963). Louise Burkhart $(1989,3)$ has succinctly summarized the tensions on the mendicants' side of the colonial process as "an odd mix of medieval theology, which insisted that all human souls were equal, Renaissance humanism, which suggested that something of worth might be found in another way of life, and Catholic intolerance, which justified - or excused - the study of pagan things on the grounds of facilitating their eradication." Colonial documents authored by indigenous peoples reveal some of the anguish suffered by those groups as they were forced to abandon their gods and rites (e.g., Klor de Alva 1980), as well as their participation in religious brotherhoods in the later colonial period (Lockhart 1992). Scholars have also examined indigenous religious agency through creative readings of Spanish-authored documents: court records from idolatry trials, for example (Tavárez 2011).

Based on Spanish and indigenous colonial documents, scholars have produced analyses, interpretations, and syntheses of the religious experience in colonial Mexico, out of which three persistent themes emerge (Graham 2011, $289-281$ provides a more extensive list).

The invisible war narrative. Robert Ricard's (1966) scholarship was the foundation for this model, which interpreted the early colonial religious experience as a war that Spanish friars won unequivocally: "at least in the field of religion, therefore, a complete rupture occurred" $(1966,286)$. This perspective was rooted in the ways that many friars understood themselves: as soldiers combating the forces of the devil and idolatry (Cervantes 1997, Ephesians 6). Ricard's interpretation, therefore, depended upon adopting the yardstick that the friars themselves used to measure the "successes" of the spiritual conquest. David Tavárez (2011) summarized the problems with this theoretical stance: "take [the friars] at their word ... would be to adopt several troublesome assumptions: that the stakes in this war were evident and transparent to both sides, that native idolaters sought to present a united front against Christianity, and that this united front depended on an antipodal version of Christianity implanted by the Devil in the natives' less discerning minds." Ricard's scholarly legacy set up and naturalized a simplistic domination/resistance binary that 
even his opponents (as in the "core/veneer" model below) implicitly adopted, though they arrived at conclusions opposite to his.

Superficial conversion, or the "core-veneer" narrative. Against Ricard's inadequate model, scholars proposed a radical alternative: the "core-veneer" model, or the notion that indigenous peoples acceded to Christianity out of coercion, but in fact maintained their own pre-Columbian beliefs. Charles Gibson was an early proponent of this idea (Gibson 1964, 98-135); Jorge Klor de Alva (1982) later emphasized this model as the most common indigenous response to Christian conversion. However, active engagement with Christianity is a near impossibility within this model, despite the fact that indigenous children grew up in the Christian faith very shortly after the conquest and claimed to be Christians (Burkhart 1998, 362; Graham 2011, 290-291). As William Hanks (Hanks 2010, 8) has noted for the Maya area: "Maya engagement with Christianity was anything but superficial or short-lived, even if it was partial, contradictory, and put to uses never envisioned by the friars."

Some scholars have modified the core-veneer model to emphasize the "resistance of culture," or the idea that colonized peoples reinterpret new events and ideas in light of their own history and social logics (Burkhart 1989; Sahlins 2009; Wernke 2007). Indeed, while continuing indigenous traditions within Christianity cannot be seen as "survivals" (i.e., an authentically indigenous "core") many aspects of modern Mexican Catholicism would be unthinkable without the influence of pre-Columbian ontologies.

Syncretism. Mounting evidence of indigenous "idolatry", resistance, and specifically indigenous contributions to Mexican Catholicism, manifested in present-day Mexican Catholicism in material culture related to ritual, elements of the physical landscape, religious art, and myriad other traditions (Burkhart 1989; Pardo 2006; Tavárez 2011, 270), led some scholars to propose a model of syncretism (Andrews and Hassig 1984), or the blending of religious traditions. Inga Clendinnen $(1990,109)$ called syncretism "that familiar mix-and-match model" because it typically focuses on the outcome of the combination of two originally static cosmologies and bodies of material culture (see also Graham 2011, 72; Hanks 2010, 94). Much recent research from archaeology and ethnohistory has shown that Spanish and indigenous religious and material traditions were not internally coherent before the Spanish military conquest, that each tradition continued to evolve both internally and as a result of contact; and that material exchanges were not politically neutral: they took place within highly unequal power structures. 
The data that I discuss in this chapter come from my excavations and analyses in Tula, Hidalgo (Figure 12.1). Tula is most famous as the capital of the Toltec civilization, which flourished there between AD 900-1150. The city also had important Late Aztec-era (AD 1350-1521) and colonial-era (AD 1521-1810) occupations, and it remains an important industrial center today. In 2013, I directed a project at two different archaeological sites in Tula: an Open Chapel constructed in $\mathrm{AD} 153^{\circ}$, and a monastery constructed in $\mathrm{AD} 155^{\circ}$ that continues to serve as Tula's cathedral and as the headquarters of the Diocese of Tula (Figure 12.2).

Because of the standing architecture and intact deposits from the earliest stages of the Christian evangelization program, Tula offers a unique opportunity to study the material culture of colonial conversion efforts in close diachronic comparison in order to understand how the evolving authority of the Church impacted material culture. In addition, it affords the opportunity to compare documentary-based accounts of sixteenth-century conversion processes against material evidence of those processes. I have chosen to highlight two bodies of material culture from my project, buildings and ceramics, because taken individually and superficially they appear to tell very different

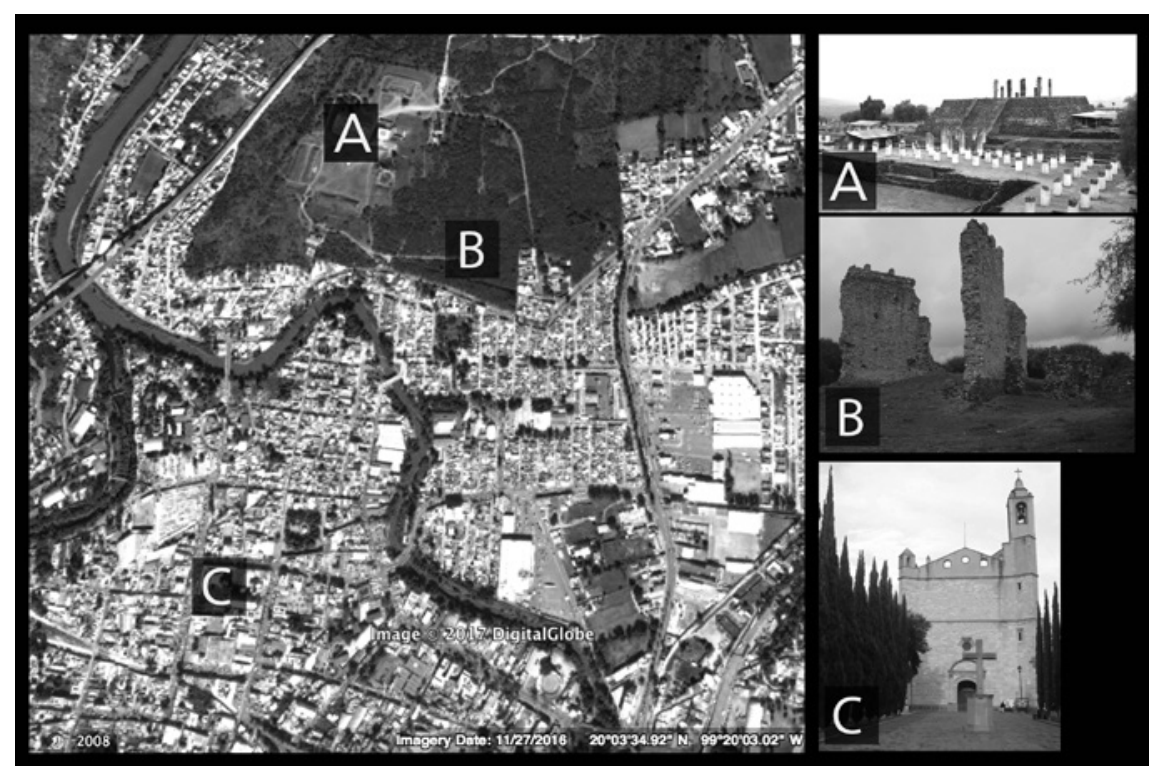

FIGURE 12.2 Relative locations of (A) Tula Grande, the Toltec ceremonial center; (B) the Open Chapel in 2008, before Carol Vazquez's restorations; (C) The Cathedral of San José MAP ADAPTED FROM DIGITALGLOBE DATA, COPYRIGHT 2017 
stories about the colonial evangelization program. Archaeologists and other scholars also tend to use these categories of material culture in very different ways: the built environment is frequently studied as a site of ideology and resistance (Hutson 2002; Solari 2013), while ceramics help us to understand ethnic and class negotiations, lived experience, and trade dynamics (Deagan 1987; Rodríguez-Alegría 2005).

\section{5} Architecture

In the Late Aztec period (AD 1350-1519), prior to the arrival of Spanish mendicants, Aztec royals ruled over a majority-Otomí population in Tula. We have very little information regarding religious activities there, but we can establish that Aztec rituals took place at the by-then-ancient Toltec ceremonial center of Tula Grande (Acosta 1956; Iverson 2017). Within Tula Grande, they made offerings and practiced rituals (such as a New Fire ceremony) that are consistent with ritual activities at other major centers, such as Templo Mayor in the Aztec capital city of Tenochtitlan (Acosta 1956; Elson and Smith 2001; López Austin and López Luján 2009). They also added an altar to the Pyramid C, one of Tula Grande's major temples (Acosta 1956, 109). The Toltec ceremonial center is, to date, the only known locus of Aztec-era ceremonial activities in Tula (Iverson 2015, 2017).

The Franciscan mendicant Friar Alonso Rengel and indigenous builders constructed the Open Chapel, the first Christian building in Tula, around AD 1530 (Ballesteros García 2003), only nine years after the Spanish military conquest of central Mexico, and only six years after the first Franciscan friars arrived in Mexico to begin a mass evangelization program in earnest. Open chapels, a form of religious architecture unique to the New World, are widely thought to be a compromise between Spanish and indigenous forms of worship (Edgerton 2001). The three walls of the Open Chapel in Tula opened to a large patio, where congregants would gather for religious festivals and to hear mass (see Figure 12.2) - echoing practices in the pre-Columbian era. The increased theatricality, ceremonialism, and pageantry of religious rites in this period is also widely thought to be an indigenous contribution to Mexican Catholicism that open chapels facilitated (Burkhart 1998; Clendinnen 1990; Córdova Tello 1992; Edgerton 2001). Another important indication of the accommodative nature of evangelism in this period at Tula is that the Chapel was built within sight of, but did not destroy or displace, the pre-Columbian Toltec ceremonial center.

My colleague Carol Vázquez has worked to excavate, consolidate, and restore the Open Chapel using an approach known as arqueotectura, or the 
archaeology of architecture (Vázquez Cibrián 2013). Her excavations revealed that the chapel was constructed in three phases, in part revealing the exigencies of the period. My excavations at the Open Chapel in 2013 complemented Vázquez's work by seeking to understand the longer constructive sequence at the chapel: two of my excavation units at the Open Chapel site were situated to understand the Chapel's articulation with earlier Aztec- and Tollan-phase occupations. In both units, we observed that the Open Chapel was built on top of pre-Hispanic architectural features. The sacristy or living quarters ${ }^{1}$ of the Open Chapel was built directly on top of a pre-Hispanic wall that was likely an Aztec construction (see Figure 12.3). We also discovered that the foundations of the northern wall the Open Chapel rested very close to was a Tollan-phase structure that featured adobe floors and a pillar (see Figure 12.3).

The Toltec building that we encountered in Operation 1 (Figure 12.3) at the Open Chapel was not a temple. Its wide adobe floors and circular pillar echo, instead, Toltec constructions that are popularly known as "palaces," such as the Palacio Quemado in Tula Grande, more likely served as elite meeting houses (Healan 2012, 101). Likewise, we did not find evidence to show that the walls and floors that we encountered in Operation 3 (Figure 12.3) served an institutional religious function. It was most likely a residence or civic building.

The early use of the Open Chapel in Tula corresponds with the broader colonial religious history of the region, in which mendicants were focused on gaining footholds in the urban areas of New Spain, learning the local languages, and eradicating the vestiges of institutional pre-Columbian religions: destroying the "pagan" temples was a major priority. Some scholars consider open chapel constructions to have served primarily as expedient preludes to the larger, more permanent, and more formal religious architecture that began to be built in the second and third decade after the conquest (Kubler 2012).

Indeed, in 1550, Friar Motolinía (the regional provincial, or regional religious authority) issued an order that a new monastery be built in Tula (Ballestros García 2003, 128). This building, the Cathedral of San José (Figure 12.2), is a large, enclosed structure that today serves as the regional headquarters of the Diocese of Tula. The fortress-like appearance of the Cathedral was not coincidental, but rather a deliberate symbolic reference to spiritual warfare based on the writings of Saint Paul (Ballesteros García 2003, 131; Ephesians 6:10-20). The Cathedral of San José likely slightly displaced the local population at Tula, as it shifted the town center approximately one kilometer to the south (Figure 12.2), much further away from the Toltec center of Tula Grande.

1 The small rooms that abutted Open Chapels could be used as sacristies, living quarters for itinerant priests, or both (Solari 2013, 15). 


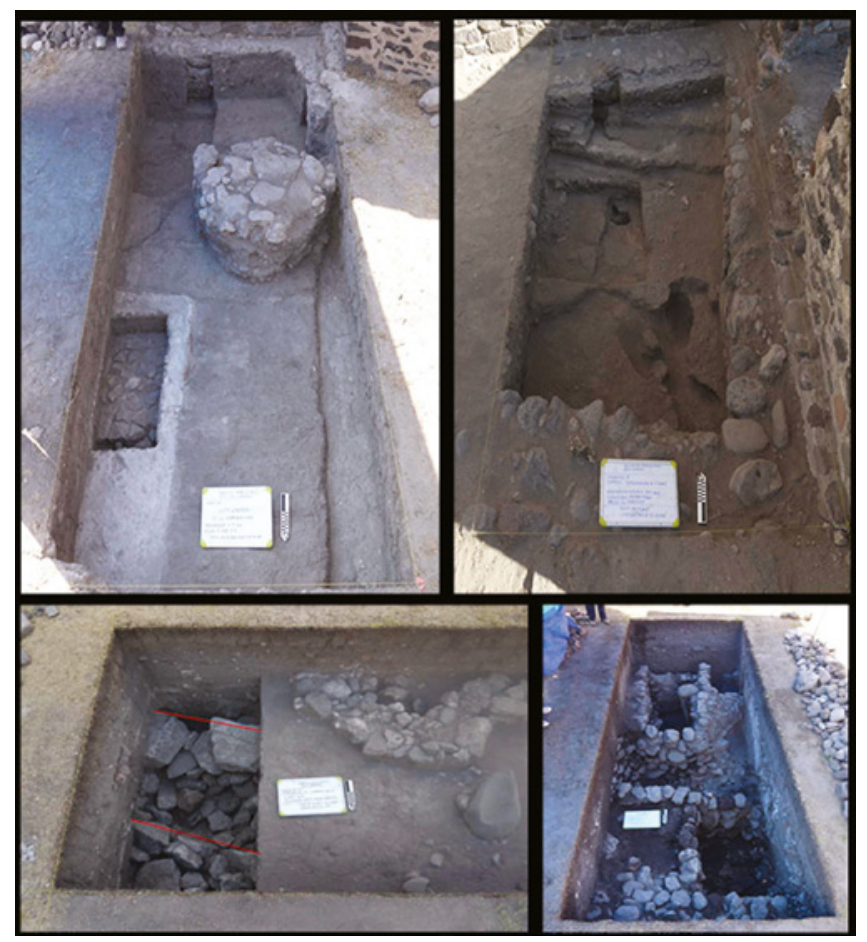

FIGURE 12.3 (Clockwise from top left) Operations 1 and 3 at the Open Chapel and Operations 6 and 7 at the Cathedral of San José. In the foreground of Operation 1, several courses of adobe, stucco, and stone foundations - likely Toltec-era - are visible. The wall in the background of the picture is the $9.4 \mathrm{~m}$-tall northern wall of the Open Chapel. At Operation 3 , the wall of the sacristy is to the east (right), and can be seen as having been constructed directly over two intersecting walls of pre-Hispanic (likely Aztec) origin. In Operations 6 and 7 , the Toltec "box" technique for platform construction is visible.

Was the abandonment of the Open Chapel and the construction of the Cathedral a straightforward symbol of the successes of the spiritual war?

Our excavations revealed a more complicated answer. First, we found that the Cathedral was constructed on what appeared (based on ceramics and construction techniques) to have been a large Toltec-era platform. This platform may have supported temples or other superstructures in the past, though evidence from my excavations was inconclusive. Second, we found the foundations of a previously unknown structure in the atrium of the Cathedral that probably served as an open chapel or for some other outdoor religious purpose during the colonial era. This indicated that the stylistic and ritual 
compromises that resulted from indigenous religious prerogatives (that is, emphasis on outdoor worship) had not disappeared once the Church consolidated its power in later decades. Instead, those changes were built into the fabric of New World Christianity from the earliest years, and continued to influence architecture even when the Church was more established and had less need to acquiesce to indigenous influence.

Questions regarding the relationships between indigenous and colonial buildings are not trivial. It is often taken as a given, particularly in colonial studies, that the act of placing important Christian monuments directly on top of the ruins of the religious monuments of conquered indigenous cultures is a transparent act of ideological warfare (Low 1995, 749 presents a concise summary of these assumptions). But buildings and landscapes are inherently multivalent; their presence and use holds different meanings for actors in different social positions (e.g. Hutson 2002, 58-60) and the meanings of the built environment change over time (Meskell 2003, 50). Even if the destruction of "idolatrous" buildings and their replacement with Christian monuments was part and parcel of religious imperialism, multiple indigenous and European understandings of the same spaces meant that the semantic significance of colonial religious buildings was never stable. As Elizabeth Graham has noted for the Maya area, “...it is unlikely that places believed by the Maya to have accumulated power would have lost their force. New spirits or supernaturals were likely to have become associated with traditional places of power..." (Graham 2011, 288).

In the Tula case notions of "ideological warfare" become even muddier because of the layered occupational sequence. On one hand, both the Open Chapel and the Cathedral were built on top of early Toltec remains that had been modified in the Aztec era, and the Open Chapel incorporated Toltec-era building materials into its fabric (Vázquez Cibrián 2013, 178). And, as many scholars have pointed out in similar cases, both buildings likely took advantage of existing religious connotations of the existing built environment and the surrounding landscape. On the other hand, however, the Open Chapel was built on top of architecture that was civic rather than religious, and neither building resulted in the destruction of the only known locus of Aztec-era ceremonial practice, the ancient center at Tula Grande, as we might expect from an evangelization program that was attempting to eradicate idolatry.

The complexities of the Tula architectural case make it hard to argue for a straightforward narrative of increasing Church authority (the top-down, "spiritual warfare" narrative of Church power). Yet both buildings represent indisputable European interventions in the Mesoamerican landscape that make it difficult to argue that indigenous subjects in Tula simply retained their core spiritual beliefs while participating in Church rites. 
The architectural evidence at the Open Chapel and the Cathedral of San José document the nearly immediate intervention of Spanish friars in the built landscapes of Mesoamerica. In contrast, the ceramic assemblages at both sites are remarkable because, superficially, they register almost complete continuity with indigenous pre-Columbian ceramic traditions.

The collections from my sites at Tula are made up of three major ceramic groups: the Toltec ceramic family, the Aztec-tradition family, and colonial ceramics comprised of European and Asian imports and their New World iterations. Toltec wares have a thick, slightly coarse, light-tan colored paste; this tradition has "little or no continuity" with the thin, hard orange pastes of the later Aztec tradition (Healan 2012, 94). The Aztec tradition is further subdivided into three major wares based on surface decoration: Plain Orange, Blackon-Orange (the ware that is still most useful for chronometric dating), and Red Wares (Minc 2017; Parsons 1966).

All three Aztec wares continued to be manufactured and used well into the colonial period, with some significant changes. First, indigenous potters developed Aztec IV, a popular Black-on-Orange decorated ware, which sometimes featured naturalistic motifs (such as birds and leaves). Second, Red Wares became much more popular, while Black-on-Orange styles began to wane. Third, indigenous potters added translucent, shiny lead glazes to thin orange vessels. However, though lead glaze was a European introduction, potters in indigenous workshops creatively innovated by using this finishing technique on existing indigenous-tradition wares (Hernández Sánchez 2011, 111-112); and thus cannot be said to be properly "European tradition." Imported colonial ceramics, such as majolica and porcelain, used materials and techniques (such tin glazes) that were not employed in the Americas until the advent of Spanish colonialism. Majolicas were soon manufactured in the New World as well chiefly in workshops in Puebla and Mexico City (Deagan 1987).

Many scholars have posited that Spanish colonists would have preferred to maintain a separation between their own material culture and that of indigenous subjects (Rodríguez-Alegría 2005 provides a summary of this assumption). Based on empirical evidence that there was no such separation, other scholars have proposed that friars would have rejected expensive imports and "elite" ceramics, such as majolica, and instead adopted indigenous ceramics because of their vows of poverty (Charlton and Fournier 1993). Rarely, however, are the changes and continuities in ceramic patterns in religious spaces attributed to indigenous preferences. 
Ceramics were not neutral objects from a religious perspective: so-called mundane objects, including ceramics, also tied into a broader concern with the sacred. Everyday serving vessels were used as offerings in burials, the New Fire Ceremony, and termination rituals (Elson and Smith 2001; Iverson 2017). Durán wrote of pre-Columbian offerings of "little bowls" to the Aztec priests (Durán 1971). Friars knew of the sacred meanings of everyday objects in celebratory contexts, but were able to convince themselves that Nahua religious customs that immediately seeped into Christianity were actually markers of true faith and enthusiastic conversion: a part of what Louise Burkhart (Burkhart 1998, $368)$ has called the friars' "ontological sleight-of-hand." For example, Friar Diego Durán wrote "it must be noted that the offerings of strings of ears of corn and flowers on the Day of Our Lady in September and during the festivities in that month are a survival of the [pagan] custom. But I believe they have been turned into an offering to His Divine Majesty" (Durán 1971, 228). It is important to note that the vessels themselves, the foods that they were used to serve, and the ceremonial contexts of which they formed a part had residual meanings that carried over from pre-Columbian celebrations: they were always multivalent. These meanings were not "survivals" - that is, the meaning of material culture was radically altered in the Christian context. On the other hand, traces of earlier sacred connotations of quotidian objects made the friars' vision of a "tabula rasa" in the New World completely untenable.

My own ceramics collections revealed some surprising findings. First, I found that it was nearly impossible to distinguish pre-Columbian and colonial contexts on the basis of ceramics alone; I had to rely on a combination of ceramic types, architectural context, and other materials, such as faunal remains (Iverson, 2015, 236). We also found a complete absence of prized imported European ceramics at both sites - this was particularly unexpected because we did find imports at non-religious sites in Tula. That is, the absence was a choice, not a question of access. I found that the entire assemblage of over 48 , ooo sherds from both sites contained only 23 sherds of New World majolica types, several of which would not have entered the archaeological record until the late colonial or early republican period - that is, the eighteenth or nineteenth centuries (Seifert 1977).

Then, I narrowed my analysis to include only early colonial contexts at both sites, excluding earlier and later periods. To my surprise, early colonial contexts contained no examples of majolica or European imports whatsoever. Instead, I found that the overwhelming majority of ceramics were of indigenous tradition. The sole contribution of European-tradition ceramic production was glazing technology, which appealed to indigenous potters and very gradually 
became more popular. However, most colonial ceramic change evident at my sites occurred within the indigenous tradition rather than as the result of imports or imitation. For example, Aztec Black-on-Orange ceramics acquired new motifs and gradually waned in popularity, while Aztec Red Wares increased in popularity (Figure 12.4). Finally, we also found several examples of Aztec-tradition censers - explicitly religious artifacts - in colonial contexts at the Open Chapel (Figure 12.5). In a plural society that included Spaniards, castas, Africans, and a majority of Otomí and Nahua-speaking peoples (Ballesteros García 2003), these patterns are significant: they mean that ceramics used in religious contexts were evolving according to indigenous ideas about the proper vessels for religious feasting and ceremony, despite access to European imports and majolica.

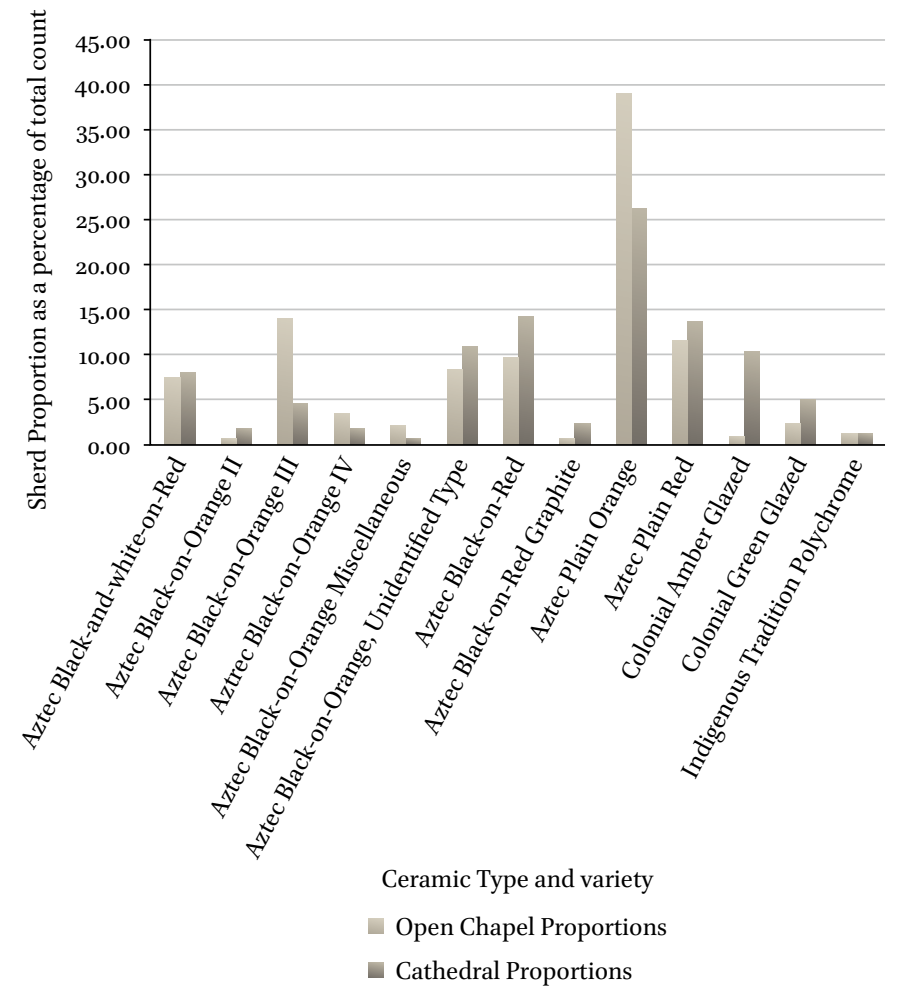

FIGURE 12.4 A comparison of proportions of diagnostic Aztec-tradition and colonial ceramic serving ware sherds encountered in colonialera contexts at the Open Chapel $(n=438)$ and the Cathedral of San José ( $\mathrm{n}=176)$ in Tula, Hidalgo. Note that Black-on-Orange types III and IV decrease over time, while four Red Ware types increase in popularity at the later Cathedral location. 


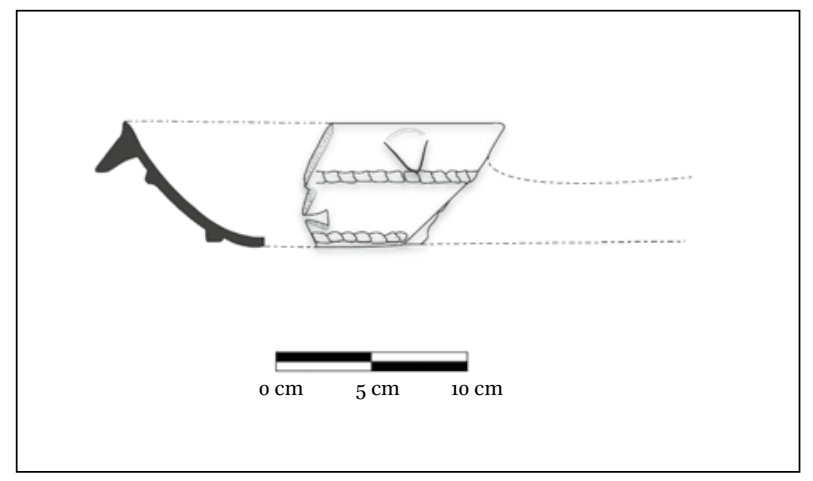

FIGURE 12.5 Aztec-tradition Texcoco Molded-Filleted style sahumador (censer) from a colonial-era context at the Open Chapel. DIGITAL ILLUSTRATION BY SHANNON DUGAN IVERSON BASED ON A DRAWING BY DANIEL CORREA

How do the ceramics findings compare to the architectural evidence at Tula? Superficially, the ceramics seem to tell the opposite story: ceramics were by far the most conservative material category, conforming to indigenous tastes over the course of several centuries even as indigenous households outside of the religious centers adopted European wares. The ceramic patterns certainly do not point to top-down European influence. Nor do they point to a lack of genuine engagement in the Church: the evidence suggests indigenous subjects celebrated and feasted at both sites. A passive blending of cultural elements is also an inappropriate explanation for these patterns: indigenous subjects innovated within their own ceramic traditions, by and large rejecting the European and Asian imports that they adopted in other contexts. However, it is crucial to remember that these vessels were being used in the service of Christian celebrations and feasts, which was a radically altered context regardless of how much indigenous subjects influenced those ceremonies.

\section{Conclusion: a Fourth Narrative}

Because of the overt and subtle violence and coercion of the evangelization program, the bulk of secondary historical literature characterizes conversion as a top-down process (the "spiritual warfare" narrative) that could be either resisted or passively accepted by indigenous peoples (the "core-veneer" narrative), but only rarely as a process in which they actively participated. The "syncretism" model of religious change does acknowledge the participation of 
indigenous agents, but it fails to account for the uneven distribution of power inherent to the colonial Church and the broader colonial enterprise.

Still, in spite of and because of the violence of the Spanish evangelization campaigns, indigenous peoples became Christian - and even in a situation of severe constraint, they made the Church their own. Their authentic, diverse engagements with that religion formed the single greatest challenge to the friars' Utopian ambitions, and created a fundamentally new Christianity in the process.

I have found Judith Butler's concept of resignification to be the most powerful framework for that pattern. Briefly, Butler's work allows us to see that concepts such as 'woman' are in fact fictions without a single material example in reality; they are constituted only through performance. Real human agents appropriate, negotiate, and reject these categories according to their particular interests and social positions, but it is never possible to assume the ideal form in reality. Change happens precisely because the real-world iterations of the categories are never perfect and always becoming; in the iterative process, they destabilize the meanings of the categories themselves.

So it was, I argue, for ideal concepts in the colonial world. "Church" as ideal category could not help but take on new significance when its material form was built with indigenous labor, using stones quarried from indigenous temples, on landscapes that had preexisting supernatural connotations. On the other hand, indigenous-tradition ceramics used in religious celebrations and feasts acquired new significance within the Christian sphere. Neither the colonizers nor the colonized ever intended colonial New World Christianity to be something distinct from the European forms of Christianity that preceded it. (Moreover, a single "European form" of Christianity never existed.) Even so, indigenous peoples exerted a powerful influence, intentional or not, on colonial structures as they negotiated the material reality of Christianity. In the process, Christianity itself changed, and its meanings destabilized.

This semantic and discursive destabilization is not infinite, however; Butler has emphasized that past semantic contexts continue to exist alongside new meanings as residues and traces (Olson and Worsham 2000, 737-737). Nor do resignifications necessarily achieve an "unmooring" of established regimes: even intentional resignifications, such as the deliberate reappropriation of the term "queer," can reinscribe particular configurations of power, or take on new and unintended meanings (Olson and Worsham 2000, 737). While indigenous contributions to Christianity fundamentally changed and challenged the Church, they did not radically alter colonial configurations of power. But they did produce multiple, conflicting ontologies that were never fully resolved, and new iterations of Christianity that privileged indigenous prerogatives. 
A "resignification" narrative of colonial religious change does not deny or overstate the powerful force exerted by colonial institutions, including the Church. But, unlike syncretic and "core-veneer" models, it has the capacity to explain the participation and influence of indigenous actors: rather than assuming covert resistance or a simple exchange of ideas and material culture, it presumes that indigenous subjects' very participation in the Church altered its meanings and steadily shifted its values toward their own prerogatives. In doing so, the model acknowledges that despite the unequal distribution of power in the early colonial period, Spanish colonial institutions were deeply dependent on preexisting indigenous structures, and deeply indebted to the active contributions of indigenous agents.

\section{Acknowledgments}

This research was funded by a National Science Foundation grant (NSF DDIG \#1156359), the University of Texas, and a Peyton and Douglas Wright Memorial Grant. Many thanks to INAH, the Diocese of Tula, Enrique RodríguezAlegría, Robert Cobean, Luis Gamboa, Heath Anderson, Rocío Cara Labrador, and my excavation and analysis crew: Abraham Leura, Pedro Rodríguez, Clara Margarita Serrano, Ana Suárez, Margarita Hernández, and Maria Elena Suárez.

\section{References}

Acosta, Jorge R. 1956. "Resumen de Los Informes de Las Exploraciones Arqueológicas En Tula, Hgo., Durante Las VI, VII Y VIII Temporadas, 1946-1950." Anales Del Instituto Nacional de Antropología E Historia 6 (8): 37-115.

Alarcón, Hernando Ruiz de. 1987. Treatise on the Heathen Superstitions That Today Live among the Indians Native to This New Spain, 1629. Vol. 164. Norman: University of Oklahoma Press.

Andrews, J. Richard and Ross Hassig. 1984. Treatise on the Heathen Superstitions That Today Live among the Indians Native to This New Spain, 1629 by Hernando Ruiz de Alarcón. Norman: University of Oklahoma Press.

Ballesteros García, Victor. 2003. "San José de Tula: Enclave Franciscano En La Cuidad de Quetzalcoatl." In Tula: Más Allá de La Zona Arqueológica, edited by Laura Elena Sotelo Santos, 127-135. Pachuca: UAEH.

Berdan, Frances F. 2014. Aztec Archaeology and Ethnohistory. New York: Cambridge University Press. 
Brumfiel, Elizabeth M. 2001. "Aztec Hearts and Minds: Religion and the State in the Aztec Empire." In Empires: Perspectives from Archaeology and History, edited by Kathleen D. Morrison, Susan E. Alcock, Carla M. Sinopoli, and Terence N D’Altroy, 283-310. New York: Cambridge University Press.

Bruner, Jerome. 2004. "Life as Narrative." Social Research 71 (3): 691-710.

Burkhart, Louise M. 1989. The Slippery Earth: Nahua-Christian Moral Dialogue in Sixteenth-Century Mexico. Tucson: University of Arizona Press.

Burkhart, Louise M. 1998. "Pious Performances: Christian Pageantry and Native Identity in Early Colonial Mexico." In Native Traditions in the Postconquest World. A Symposium at Dubarton Oaks, 2nd through 4th October 1992, edited by Elizabeth Hill Boone and Tom Cummins, 361-381. Washington, D.C.: Dumbarton Oaks Research Library and Collection.

Butler, Judith. 1990. "Gender Trouble, Feminist Theory, and Psychoanalytic Discourse." In Gender Trouble: Feminism and the subversion of identity, edited by Butler Judith, 324-341. London and New York: Routledge.

Cervantes, Fernando. 1997. The Devil in the New World: The Impact of Diabolism in New Spain. New Haven: Yale University Press.

Charlton, Thomas H., and Patricia Fournier. 1993. "Urban and Rural Dimensions of the Contact Period." In Ethnohistory and Archaeology. Approaches to Postcontact Change in the Americas, edited by J. Daniel Rogers and Samuel M. Wilson, 201-220. New York: Springer.

Christian, William A. 1989. Local Religion in Sixteenth-Century Spain. Princeton: Princeton University Press.

Clendinnen, Inga. 1990. 'Ways to the Sacred: Reconstructing 'Religion' in Sixteenth Century Mexico." History and Anthropology 5 (1): 105-141.

Connerton, Paul. 1989. How Societies Remember. Cambridge University Press.

Córdova Tello, Mario. 1992. El Convento de San Miguel de Huejotzingo, Puebla. Arqueología Histórica. Mexico City: Instituto Nacional de Antropología e Historia.

Deagan, Kathleen. 1987. Artifacts of the Spanish Colonies of Florida and the Caribbean, 1500-180o: Volume 1-Ceramics, Glassware and Beads. Washington, D.C.: Smithsonian Institution.

Díaz, Bernal. 1963. The Conquest of New Spain. Translated by John M. Cohen. London: Penguin Books.

Durán, Fray Diego. 1971. Book of the Gods and Rites and the Ancient Calendar, edited by Fernando Horcasitas and Doris Heyden. Norman: University of Oklahoma Press.

Edgerton, Samuel Y. 2001. Theaters of Conversion: Religious Architecture and Indian Artisans in Colonial Mexico. Albuquerque: University of New Mexico Press.

Elson, Christina M. and Michael E. Smith. 2001. "Archaeological Deposits from the Aztec New Fire Ceremony." Ancient Mesoamerica 12 (2): 157-174. 
Gibson, Charles. 1964. The Aztecs Under Spanish Rule: A History of the Indians of the Valley of Mexico, 1519-1810. Stanford: Stanford University Press.

Gómez-Herrero, Fernando. 2001. Good Places and Non-Places in Colonial Mexico: The Figure of Vasco de Quiroga (1470-1565). Lanham: University Press of America.

Graham, Elizabeth. 2011. Maya Christians and Their Churches in Sixteenth-Century Belize. Gainesville: University Press of Florida.

Hanks, William F. 2010. Converting Words: Maya in the Age of the Cross. Berkeley: University of California Press.

Healan, Dan M. 2012. “The Archaeology of Tula, Hidalgo, Mexico." Journal of Archaeological Research 20 (1): 53-115.

Hernández Sánchez, Gilda. 2011. Ceramics and the Spanish Conquest: Response and Continuity of Indigenous Pottery Technology in Central Mexico. Boston: Brill.

Hutson, Scott R. 2002. "Built Space and Bad Subjects Domination and Resistance at Monte Albán, Oaxaca, Mexico." Journal of Social Archaeology 2 (1):53-80.

Iverson, Shannon Dugan. 2015. "The Material Culture of Religion and Ritual: An Investigation of Social Change in the Aztec-to-Colonial Transition at Tula, Hidalgo." PhD diss., University of Texas at Austin.

Iverson, Shannon Dugan. 2017. "The Enduring Toltecs: History and Truth during the Aztec- to-Colonial Transition at Tula, Hidalgo." Journal of Archaeological Method and Theory 24 (1) 90-116.

Jameson, Fredric. 2013. The Political Unconscious: Narrative as a Socially Symbolic Act. London: Routledge.

Klor de Alva, J. Jorge. 1980. “The Aztec-Spanish Dialogues of 1524." Alcheringa 4 (2): 52-193.

Klor de Alva, J. Jorge. 1982. "Spiritual Conflict and Accommodation in New Spain: Toward a Typology of Aztec Responses to Christianity." In The Inca and Aztec States 1400 (180o): Anthropology and History (Studies in Anthropology), edited by George Collier, Renato I. Rosaldo, and John D. Wirth, 345-366. Cambridge: Academic Press.

Kubler, George. 2012. Arquitectura Mexicana Del Siglo XVI. San Diego: Fondo de Cultura Economica USA.

Lockhart, James. 1992. The Nahuas after the Conquest: A Social and Cultural History of the Indians of Central Mexico, Sixteenth through Eighteenth Centuries. Stanford: Stanford University Press.

López Austin, Alfredo, and Leonardo López Luján. 2000. "The Myth and Reality of Zuyuá: The Feathered Serpent and Mesoamerican Transformations from the Classic to the Postclassic." In Mesoamerica's Classic Heritage: From Teotihuacan to the Aztecs, edited by David Carrasco, Lindsay Jones, and Scott Sessions, 21-84. Boulder: University Press of Colorado.

López Austin, Alfredo, and Leonardo López Luján. 2009. Monte Sagrado-Templo Mayor. Mexico: INAH. 
Low, Setha M. 1995. "Indigenous Architecture and the Spanish American Plaza in Mesoamerica and the Caribbean." American Anthropologist 97 (4): 748-762.

Mendieta, Gerónimo de. 1870. Historia Eclesiástica Indiana. Vol. 3. Antigua librería [Printed for F. Diaz de Leon and S. White].

Meskell, Lynn. 2003. "Memory's Materiality: Ancestral Presence, Commemorative Practice and Disjunctive Locales." In Archaeologies of Memory, edited by Ruth M. Van Dyke and Susan E. Alcock. Wiley Online Library.

Minc, Leah D. 2017. "Pottery and the Potter's Craft in the Aztec Heartland." In The Oxford Handbook of the Aztecs, edited by Deborah L. Nichols and Enrique RodríguezAlegría, 355-374. New York: Oxford University Press.

Olson, Gary A., and Lynn Worsham. 2000. "Changing the Subject: Judith Butler's Politics of Radical Resignification." JAC 20 (4): 727-765.

Pardo, Osvaldo F. 2006. The Origins of Mexican Catholicism: Nahua Rituals and Christian Sacraments in Sixteenth-Century Mexico. Ann Arbor: University of Michigan Press.

Parsons, Jeffrey Robinson. 1966. "The Aztec Ceramic Sequence in the Teotihuacan Valley, Mexico." Unpublished PhD diss., University of Michigan.

Restall, Matthew. 2004. Seven Myths of the Spanish Conquest. Oxford University Press.

Ricard, Robert. 1966. The Spiritual Conquest of México. Translated by Leslie Byrd Simpson. Berkeley: University of California Press.

Rodríguez-Alegría, Enrique. 2005. "Eating like an Indian." Current Anthropology 46 (4): $55^{1-573}$.

Rodríguez-Alegría, Enrique. 2008. "Narratives of Conquest, Colonialism, and CuttingEdge Technology." American Anthropologist 110 (1): 33-43.

Sahagún, Bernardino de. 1950. General History of the Things of New Spain: Florentine Codex. Translated by Arthur J.O. Anderson and Charles E. Dibble. Santa Fe: School of American Research.

Sahlins, Marshall D. 2009. Historical Metaphors and Mythical Realities: Structure in the Early History of the Sandwich Islands Kingdom. Ann Arbor: University of Michigan Press.

Schwaller, John Frederick. 2011. The History of the Catholic Church in Latin America: From Conquest to Revolution and beyond. New York: New York University Press.

Seifert, Donna J. 1977. "Archaeological Majolicas of the Rural Teotihuacán Valley, Mexico." PhD diss., University of Iowa.

Solari, Amara. 2013. Maya Ideologies of the Sacred: The Transfiguration of Space in Colonial Yucatan. Austin: University of Texas Press.

Tavárez, David. 2011. The Invisible War: Indigenous Devotions, Discipline, and Dissent in Colonial Mexico. Stanford: Stanford University Press. 
Vázquez Cibrián, Carol. 2013. "La Edificación de Una Historia: Arqueoarquitectónico de La Capilla Abierta de Tula." PhD diss., Escuela Nacional de Antropología e historia, Mexico.

Wernke, Steven A. 2007. "Analogy or Erasure? Dialectics of Religious Transformation in the Early Doctrinas of the Colca Valley, Peru." International Journal of Historical Archaeology 11 (2): 152-182.

White, Hayden. 2009. The Content of the Form: Narrative Discourse and Historical Representation. Baltimore: Johns Hopkins University Press. 